\title{
29
}

\section{REBELS, SMUGGLERS AND (THE PITFALLS OF) ECONOMIC PACIFICATION}

\author{
David Brenner
}

\section{Introduction}

Rebels and smugglers often make natural bedfellows. This is due to the clandestine and peripatetic nature of both rebel movements and smuggling economies, as well as their borderland geographies. State actors thus seek to dry up smuggling flows in order to erode the revenue streams of armed groups that tax smuggling operators or operate smuggling economies themselves. Economic pacification strategies can pursue breaking up the rebel-smuggler nexus in two different ways. ${ }^{1}$ The state can attempt to restrict the flow of goods that are linked to armed group funding by sanctioning the trade of certain commodities. Alternatively, the state can aim to undercut the profit margins of smuggling operations by liberalising restrictive trade regimes, thereby turning smuggling into official trade.

The effect that economic pacification has on the dynamics of conflict are, however, far from straightforward. As this chapter suggests, such strategies can, in fact, increase rather than decrease violence, conflict and insecurity. This is not only because economic interventions in contexts of conflict can shift the incentives of warring factions in unforeseen ways. More importantly, economistic approaches to conflict operate on limited assumptions about the nature of political violence and consequently fail at addressing the underlying political causes of conflict. To explore some of the unintended effects and pitfalls of economic pacification, the following chapter will proceed as follows. It will first discuss the nexus between smuggling and rebellion and contextualise economic pacification policies on the basis of political economy scholarship. It will then explore two different approaches to eroding smuggling revenues through two empirical case studies. The chapter will look to attempts of restricting smuggling economies in the case of US sanctions on so-called conflict minerals in the border areas of the eastern Democratic Republic of the Congo (DRC). It will then turn to eastern Myanmar for an example where state policy sought to undermine rebel revenues by liberalising rather than restricting border trade. In both cases, economic policies to weaken rebel groups have not translated into a decrease of insecurity and violence, let alone in the pacification of armed conflict itself. 


\section{Smuggling as a source of rebel revenue}

Smuggling makes for a good source of revenue for rebel movements. Taking up arms against the state is costly but illegal. In order to fund a rebel movement, including the purchase of arms and munition, the mobilisation of people, the training and payment of recruits, the provision of services to people in rebel-held territories, among other needs, rebels must generate revenue. As rebels cannot fund themselves through formal economic activities, partaking in illicit economies, including cross-border smuggling, is imperative. Moreover, arms and munition are normally not available for purchase through legal channels and must be acquired on the black market (at least in the absence of other sources).

At the same time, the black market itself often expands in contexts of war as smuggling becomes the lifeline for many people in a context where large parts of the formal economy collapse. From besieged Sarajevo to the Afghan and Myanmar borderlands, during war people often depend on smuggling to make a living while communities depend on smugglers for everyday goods (Goodhand 2004, Andreas 2011, Brenner 2019). From the rebel perspective, the clandestine and peripatetic nature of smuggling economies is compatible with the mobility and surreptitiousness dictated by guerrilla warfare. Most formal economies, including agriculture, manufacturing or resource extraction, are dependent on at least relatively stable territorial control. By contrast, smuggling or taxing smuggling operators is feasible in contexts of lose, fragmented and often mixed control of territory. Even if rebel movements rule territory as a quasi-state within the state, however, smuggling remains key to their economic orders. This is because flows of goods within or across rebel territory avoid official tax and tariffs, by definition turning trade into smuggling. This is most pronounced when rebel territory spans inter-state borders (Weigand 2020, pp. 134-135).

In fact, many rebel groups are located in remote border areas where smugglers operate across international borders. This is due to a mix of factors. Borderlands are geographically distanced from the centre of state power. While borders themselves are mostly highly securitised, borderlands are often less territorialised in terms of the geographic reach and penetration of state power. In many contexts, it is simply more feasible to recruit and mobilise armed resistance to the state (Buhaug and Gates 2002). This lack of state territorialisation in many borderlands is far from coincidental. The drawing of borders itself left many borderland communities disaffected with the nation-states in which they had come to be placed (Korf and Raeymaekers 2013). The contested nature of the state in many borderlands is thus a direct effect of state formation processes. This is particularly important for contemporary conflicts in the Global South, most of which are ethnonational conflicts directly linked to colonial border drawing and state formation (Wimmer 2012, pp. 2-3, Mamdani 2018).

To sum up, the organisational mode and particular geography of smuggling turn it into an ideal source of revenue for rebel groups. This is true for a range of contemporary conflicts: nonstate armed groups in the eastern DRC smuggle minerals and marijuana (Seay 2012); rebels in Myanmar are involved in the smuggling of timber and gemstones (Brenner 2019); and insurgents in Syria engage in the smuggling of weapons and everyday goods (Herbert 2014). The reliance of rebels on illicit economies in general and commodity smuggling in particular is anything but new. This is despite the oft-heard notion that many rebel groups were less reliant on illicit economies during the Cold War because they received financial support from one or the other superpower (e.g., Kaldor 2012; Malešević 2008). Despite Cold War alliances, rebel groups often sought financial self-reliance. Notwithstanding US support, the Afghan mujahideen, for instance, financed their struggle against the Soviet Union by smuggling heroin, just as the Angolan UNITA financed its operations through ivory and diamond smuggling (Naylor 
1993). In some cases, the US even aided the smuggling activities of its non-state allies in order to ensure their financial self-reliance. In the Golden Triangle of Southeast Asia (the restive border regions of Myanmar, China, Laos and Thailand), the CIA aided anti-communist forces during the Cold War by providing logistical support for large-scale smuggling of heroine, including transportation in CIA airplanes, in effect turning the region into one of the world's largest exporters of narcotics (McCoy 1972).

Despite this long-standing nexus between smuggling and armed conflict, the issue of armed group financing has only attracted scholarly interests since the political economy turn of Conflict Studies in the 1990s. Grappling with the post-Cold War outbreak of new or thought-to-be frozen conflicts in the Global South, some voices initially forwarded culturalist explanations that stressed ethnic difference as the main driver of civil wars from Yugoslavia, to Rwanda and Sierra Leone (Huntington 1993, Kaplan 1994). Others, however, stressed the economic rationale underlying these armed conflicts, highlighting how elites took an interest in perpetuating violence because they profited from globalised war economies (Collier and Hoeffler 1998, Keen 2008, Kaldor 2012). Political economists dedicated considerable work to disentangling different types and facets of war economies and how they relate to conflict dynamics. They have, for instance, discussed what kind of resources are more or less associated with violent conflicts, given how lootable or transportable they are (Ross 2004, Le Billon 2012, Rigterink 2020). Their findings stress that the state is mostly as deeply implicated in the economic orders that emerge during protracted armed conflict as are non-state actors (Berdal and Keen 1997). Smugglers, for instance, often cooperate with state actors, such as border officials and security forces. This is particularly so for large-scale smuggling operations that need access to the infrastructure of the formal economy, such as ports and airports (Weigand 2020, pp. 123-125). In a similar vein, critical scholars have highlighted the need to analyse war economies in a regional and global perspective rather than simply locating them within one or another seemingly bounded nation-state container (Duffield 1999, Pugh et al. 2004, Keen 2008). Building on this, discussions focused on the implications of war economies on war-to-peace transitions, including conflict resolution, post-war reconstruction, state-and peacebuilding (Goodhand 2004, Turner and Pugh 2006, Le Billon and Nicholls 2007, Wennmann 2009).

\section{Economic pacification and its pitfalls}

From an economic perspective, ending armed conflict is about making conflict a) less economically feasible by undercutting the revenue base of warring factions and b) less economically desirable by decreasing the profitability for conflict entrepreneurs. While political economy scholars of civil war stress the deep involvement of the state in most war economies, economic pacification policies predominantly target non-state armed groups. After all, policies are formulated by states (or state-based international organisations). Economic pacification of the rebel-smuggler nexus thus aims at undercutting the revenues that non-state armed groups generate by smuggling or taxing smuggling operators. Generally speaking, the state can attempt this in two different ways. On the one hand, the state can attempt to restrict the flow of goods linked to armed group funding with targeted sanctions. On the other hand, the state can aim to undercut the profit margins of smuggling operators by liberalising restrictive trade regimes, thereby turning smuggling into official trade.

The remainder of this chapter will explore both approaches through two different contexts: a) international sanctions on so-called conflict minerals smuggled from the eastern DRC; and b) the liberalisation of border trade in eastern Myanmar. Both cases compare and contrast in ways 
that illuminate different economic pacification attempts as well as their unintended consequences. In the case of the DRC, the US sanctioned the cross-border trade of industrial minerals in an attempt to erode the funding base of non-state armed groups in northern Kivu. In the case of Myanmar, the country's military regime liberalised a highly restrictive border trade regime in order to undercut the funding of rebels that control the main smuggling routes to Thailand. While both policies decreased the immediate smuggling revenues for non-state armed groups, they did not lead to a reduction of conflict, violence or insecurity.

\section{Restricting border trade: the case of the DRC}

Economic sanctions are an established tool in contemporary international relations. States, groups of states, and international organisations regularly use sanctions to force governments into political concessions by restricting flows of goods, finance and people (Jones 2014, p. 1). In the context of civil wars, non-state armed groups have also become the target of international sanctions as a means of economic pacification. Such sanctions include the freezing of international assets and capital of non-state combatants and restricting the smuggling of commodities from or to territories controlled by non-state-armed groups. In 1992, the United Nations Security Council (UNSC) has, for instance, imposed an embargo on the export of timber from and the import of petroleum to areas controlled by the Khmer Rouge (resolution 792) (Lapaš 2010). In 1998, the UNSC legislated a ban on the trade of diamonds from UNITA-controlled areas of Angola (resolution 1173). The latter developed into the Kimberley Protocol Certification Scheme, a multi-stakeholder effort to prevent so-called 'blood diamonds' - i.e., diamonds that are mined in conflict areas - from being sold internationally (Ibid.).

Similarly, section 1502 of the Dodd-Frank Act (hereafter Dodd-Frank) seeks to restrict what has come to be known as 'conflict minerals' from entering the global market. The law was passed by US Congress as a wide-ranging legislation on global finance regulation under the Obama administration in 2010. The insertion of the 'conflict minerals section' was due to considerable lobbying efforts by human rights groups. It requires US electronics manufacturers to trace and report the source of minerals from the eastern DRC and certify that they are 'conflict free.' Conflict minerals from the eastern Congo include gold and the '3Ts:' tin; tantalum; and tungsten. These metals are relatively rare but essential for the production of consumer electronics such as mobile phones and computers. The eastern DRC provinces of North and South Kivu, Maniema, Orientale, and Katanga are among the few places in the world where all four metals can be found in relatively large quantities.

Eastern DRC - especially the Kivu provinces - is also home to one of sub-Saharan Africa's most protracted armed conflicts among a variety of non-state armed groups and the Congolese state. Campaigners behind Dodd-Frank - locally known as 'Obama's law' - view the profits from extracting and trading gold and the '3Ts' as the main driver of armed conflict as well as its associated human rights violations (Bafilemba et al. 2014). Armed groups are estimated to have generated $\$ 185$ million per year from the trade of these minerals before Dodd-Frank by controlling mines and smuggle operations (Ibid.). According to the Enough Project - one of the main organisations behind Dodd-Frank - the act has been highly successful in eroding these revenues by squeezing armed actors out of the mineral business. Following their logic, the act created a certification scheme for conflict-free minerals, which made non-certified minerals realise much lower market prices (30\% to 60\% less). This, in turn, made mining and trading much less profitable for armed actors (Ibid.).

Independent assessments of Dodd-Frank, however, paint a much more sobering picture. Scholars point to both important regulatory loopholes and unintended consequences of conflict 
and violence (Seay 2012, Cuvelier, Van Bockstael, et al. 2014, Parker and Vadheim 2017, Stoop et al. 2018). In terms of loopholes, it is far from clear whether Dodd-Frank has an actual impact on the funding base of armed groups in the DRC. As the act's co-sponsor Barney Frank put it: 'The purpose is to cut off funding to people who kill people' (Aronson 2011). To be sure, Dodd-Frank worked to reduce the profitability of conflict minerals. This was because Dodd-Frank acted as a de-facto boycott of conflict minerals from eastern DRC. The cheapest way to comply with the new legislation for US manufacturers was not to certify minerals from eastern DRC as 'conflict free' but to avoid sourcing minerals from the country's conflict zone altogether (Parker and Vadheim 2017, p. 9). That said, the most profitable 'conflict mineral' in the region - gold - has been exempted from regulation under Dodd-Frank, which only imposed certification on the '3Ts.' This is because most of the gold from DRC is exported to the jewellery market rather than the electronics sector, and gold is much less traceable than the '3Ts' for geological reasons (Parker and Vadheim 2017, p. 11). According to a report produced by the Congolese senate in 2009 , about $\$ 1.24$ billion worth of gold - or $98 \%$ of all gold mined in the DRC - was smuggled out of the country per year (de Koning 2010, Bafilemba et al. 2014, p. 5).

Dodd-Frank has not eroded the funding of armed groups in the eastern DRC in a significant way. Besides falling back on revenues from gold mining, armed groups also increased smuggling of other commodities - including beer, cigarettes, cannabis and palm oil - in order to make up for the shortfalls of funds produced from the '3Ts' (Seay 2012, p. 16, Parker and Vadheim 2017, p. 11). Moreover, it is not clear whether Dodd-Frank actually decreased conflict, violence and insecurity or had the contrary effect. Indeed, a variety of studies indicate the latter. Georeferenced data suggests that fighting among armed groups might have intensified, especially in areas of gold mining sites, as competition over the last unregulated conflict mineral increased due to banning the '3Ts' (Parker and Vadheim 2017, p. 41, Stoop et al. 2018, p. 2). Moreover, armed group violence against civilians might have also increased because some armed groups who governed mining sites before and provided basic protection now fell back on looting to make up for their lost income (Parker and Vadheim 2017, p. 3, Stoop et al. 2018, p. 2). In many communities of eastern DRC, mining moreover constitutes the only paid work available. Despite the deplorable conditions in which many miners work, the ban on minerals has led to large-scale unemployment and loss of livelihoods in the region (Seay 2012, pp. 14-15). After Dodd-Frank came into effect, local researchers estimated that about one to two million artisanal miners in eastern Congo lost their jobs (Ibid.). This had a paralysing effect on the regional economy more generally (Cuvelier, Van Bockstael, et al. 2014). Consequently, human insecurity seems to have risen considerably as a result of Dodd-Frank. Infant death rates in policyaffected mining communities, for instance, increased by at least 143\% (Parker et al. 2016).

On a more general level, attempting to reduce conflict, violence and insecurity by restricting the smuggle of minerals mistakes the means for the ends of violence. In eastern Congo - as arguably in all contexts of armed conflict - war economies are but one driver of conflict. In fact, the main advocates of Dodd-Frank reduce a protracted conflict rooted in long imperial histories to a monocausal economistic logic of profiteering. To be clear, country experts confirm the importance of violent economies beyond conflict minerals for understanding the dynamics of conflict in the eastern DRC (Laudati 2013, Verweijen 2013). They also, however, highlight the need for understanding and addressing dynamics of ethnic identity, the predatory and exclusionary nature of state institutions, as well as competing land claims among different communities in a conflict that is bound up with a wider, regional complex of conflicts (Vlassenroot 2002, Van Acker 2005, Autesserre 2006, Prunier 2008). Country experts thus point out that the key problem of economic pacification policies in the DRC is their underlying reductionist 
assumptions about the relationship between illicit economies and armed conflict, as well as the thin empirical evidence that is used to substantiate these claims (Cuvelier, Vlassenroot, et al. 2014).

\section{Liberalising border trade: the case of Myanmar}

Dodd-Frank illustrated some of the pitfalls and unintended consequences of economic interventions that aim at eroding armed group finances by restricting transborder trade in certain commodities. In contrast to restricting border trade with economic sanctions, economic pacification can also aim at eroding armed group revenues by liberalising the trade in commodities from which armed groups benefit. While this is a less common approach in contexts of civil war, it is an established policy debate in the context of organised crime profiting from illegal market activities (Lavezzi 2014). One way of undercutting the profits of organised crime is to decriminalise its trade and the commodities or activities it is based on. Prohibiting commodities and activities does not only push their production, trade and operation into the realm of the illegal. It also increases their profitability. US prohibition of alcohol in the 1920s and 1930s, for instance, gave unprecedented rise to the mafia in America after an 'entire industry - one of the most important in the country - had been gifted by the government to gangsters' (Dash cited as in Mappen 2013, p. 5). Decriminalising activities ranging from narcotics, to gambling and prostitution is often debated as one way of combatting organised crime (Lavezzi 2014). Some scholars and activists thus view the liberalisation of drugs as an alternative, and more effective way of addressing the war economy in contexts like Colombia, especially when compared to highly restrictive and militarised policies such as the US-funded Plan Colombia (Francis and Mauser 2011, Vergara 2014).

In the context of economic pacification, Myanmar is an instructive place to study the effects of government policies aimed at eroding the funding base of armed groups by liberalising border trade. This is because rebel groups in the Southeast Asian country have long profited from one of the least open border trade regimes. Between 1962 and 1988, the military regime in Burma ${ }^{2}$ followed a self-isolationist economic policy. Under the so-called 'Burmese Way to Socialism' Burma nationalised all trade and levied heavy tariffs on imports in order to build an independent economy with the effect that people in Burma suffered an immense shortage of everyday goods. At the same time, almost all of the country's borderlands have come under the control of numerous armed groups since the 1950s (Jones 2014, p. 786). Most of these armed groups emerged as ethnonational rebel movements seeking more autonomy or outright independence from an ethnocratic postcolonial state after the failure of post-independence settlement between the country's ethnic majority and its ethnic minorities over questions of equality and power sharing. Other armed groups included the Chinese-backed Communist Party of Burma, itself largely recruited from ethnic minority communities in the country's northern border areas (Smith 1999, pp. 102-110, Brenner 2019, pp. 35-40).

The combination of official trade restriction and de-facto lack of state control over the country's border areas meant that the black market in Burma was booming during much of the Cold War. While everyday goods - such as fuel, medicine, agricultural machinery and textiles were smuggled into the country in vast quantities, they were paid for with the illicit export of raw materials, including opium, timber, gemstones, rice and cattle. According to estimates, Burma's smuggling economy comprised of about $40 \%$ of the country's gross national product in 1988 , equivalent to approximately $\$ 3$ billion (Smith 1999, p. 25). Rebel groups controlling most of the smuggle routes in and out of the country were the main beneficiaries of illicit trade. They taxed smuggling operators between $5 \%$ and $10 \%$, so smuggling in fact became the 'armed 
opposition's lifeblood' (Smith 1999, p. 99). One Karen rebel officer, for instance, recollects that during the 1980s the Karen rebellion made several thousands of US dollars at one smuggle gate between Thailand and Myanmar per day (Ralph and Sheera 2020, p. 83). Consequently, some of the heftiest battles in Myanmar's civil war have been fought over smuggling routes and border gates (Ibid., pp. 83-87).

In fact, this is a dynamic that can be observed even today as large parts of Myanmar's borderlands, including border crossings, remain under the control of non-state armed groups. Since the 1990s, however, smuggling revenues declined steeply for many of the country's rebel movements. Partly this was because Myanmar's armed forces have managed to take control over some of the country's main trading routes. More important was a strategy of economic liberalisation. By abandoning self-isolationist economic policies and legalising most transborder trade with its neighbours, the ratio of smuggling to official trade from 1990 to 2005 fell from 85 to $50 \%$ (Jones 2014 , p. 794). This was not a purely economic measure, but formed part of a bundle of policy reforms with which the Myanmar state aimed to pacify its restive border areas and consolidate its own presence instead (Jones 2014, Brenner 2019, pp. 40-46). It is important to note, though, that the consolidation of state control over transborder economic flows has been highly uneven. This is dependent on territorial control, state-armed group relations in a given region, and the involvement of military units in smuggling. It also depends on legal status of commodities and amount of protective tariffs on certain economies (Meehan 2011, Woods 2011, Jones 2014). In 2013, for instance, Thai beer, Malaysian palm oil, and second-hand cars from Japan were still smuggled on a large scale from Thailand to Myanmar (Figure 29.1).

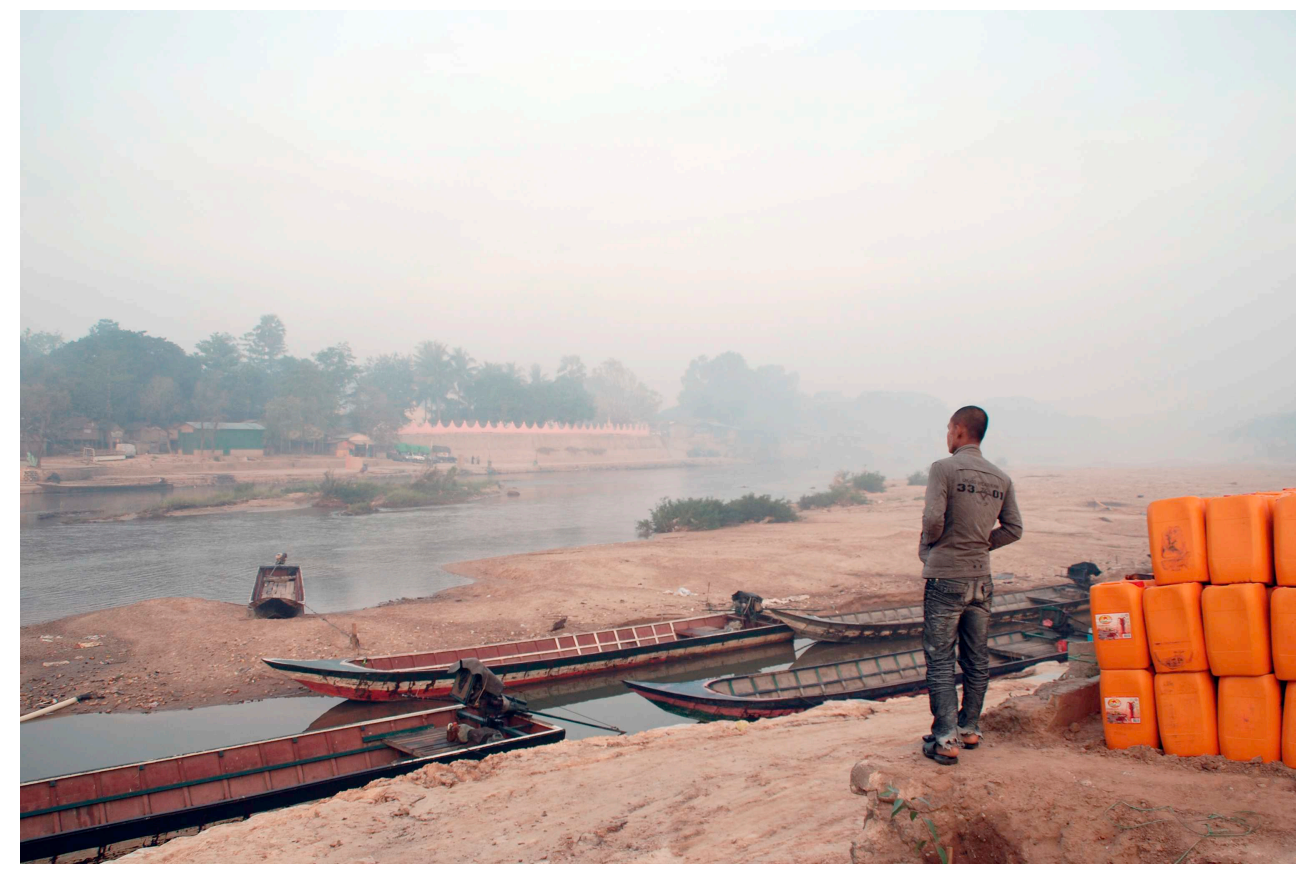

Figure 29.1 A palm oil smuggler on the Moei River that marks the border between Myanmar and Thailand

Source: author (David Brenner) 
This uneven and contested nature of state consolidation over the country's smuggling economy has not led to the pacification of Myanmar's protracted civil war. Similar to the sanctions on smuggling minerals from the DRC, liberalising border trade has transformed conflict, violence and insecurity. While economic opening up has eroded the revenue base of some armed groups - such as Karen rebellion - it empowered other armed actors, mostly militia groups that emerged as splinter factions of ethnic rebel movements and operate in close cooperation with the state (Buchanan 2016). Many of them benefit from the increased openness of trade in a context where the rule of law remains suspended. This is not least because there is insufficient interest from powerful state authorities in bringing the country's smuggling economy into the formal and legal fold. Military and civilian officials themselves remain invested in some of the country's most lucrative smuggling industries, including the country's jade and narcotics industries, both of which are deeply intertwined with the formal economy (Meehan 2011, Jones 2014, Weigand 2020, pp. 43-74).

Consequently, insecurity and violence for civilians in Myanmar's border areas has not receded in areas where rebel groups themselves were weakened by way of economic pacification. On the contrary, civilians need to navigate an even greater plethora of armed actors today than they had to in the past (Brenner 2019, pp. 56-57). This also holds true for the places where the actual fighting between warring factions has stopped (Hedström and Olivius 2020). In large parts of Myanmar's border areas, the civil war continues unabated. At the time of writing, Myanmar's army is battling various rebellions in the country. As with the DRC, this is mainly because economic pacification policies in Myanmar do not address the root causes of political conflict. While they might have achieved the temporary erosion of rebel revenues or even the partial co-optation of rebel elites, they do not address underlying political demands and grievances among large parts of the country's ethnic minority communities. As a matter of fact, attempts at economic pacification that do not address the political dimensions of conflict are likely to result in the remobilisation of armed resistance, as seen in the country's north (Brenner 2019, pp. 98-102).

\section{Conclusion}

Smuggling is a well-suited economic activity for rebel movements to fund their struggle against the state. This is not least because the modus operandi and geography of smuggling operators is often compatible with the guerrilla operations of armed clandestine movements. Unsurprisingly then, pacification strategies aim at undercutting lucrative smuggling operations by restricting illicit trade flows or formalising them through liberalising trade regimes. This chapter explored two cases that shed light on such strategies and their pitfalls. It first traced the effects of section 1502 of the Dodd-Frank Act, a US law that effectively works as a sanction on so-called 'conflict minerals' in the eastern DRC. It then reviewed how Myanmar's military regime liberalised border trade with its neighbours with the aim of eroding smuggling revenues of border-based rebel movements. In both contexts, economic pacification policies ultimately failed to mitigate conflict, violence and insecurity.

While Dodd-Frank succeeded in squeezing armed actors out of the trade of certain minerals in the eastern DRC, it has neither resulted in the erosion of armed group funding nor in reducing the intensity of armed conflict and its ramifications for the civilian population. In fact, armed groups could easily switch to other modes of funding, including the mining and smuggling of gold and the looting of civilians. This, in turn, increased fighting and insecurity in the region. Moreover, the boycott on minerals from the eastern DRC decimated the local economy, having disastrous effects on the human security of local communities. Economic 
pacification strategies in Myanmar also led to mixed results. Liberalising border trade in the attempt to bring clandestine economies under state control worked to undercut smuggling revenues of some rebel groups. State consolidation, however, has been highly contested and uneven. This is not least because powerful state actors themselves remain deeply invested in the country's smuggling economies. Rather than formalising most border trade completely, the state has thus come to rely more heavily on militias in governing illicit trade, leading to the proliferation of armed actors in the Myanmar's border areas. Shifting economic flows also led to the increased fragmentation and power struggle within armed movements, as well as renewed armed conflict.

Both cases demonstrate that the main problem with economic pacification strategies is not so much that shifting economic incentive structures can have unintended consequences that increase rather than decrease conflict, violence and insecurity. This is part of the story. The main pitfall of economic pacification strategies lies in their limited assumptions. In fact, they are born out of a reductionist understanding that views economic rationale and feasibility rather than political motivations as the main drivers of contemporary armed conflict. This understanding has increasingly underpinned the disciplinary study of civil war and rebel groups in political science, international relations, and development studies ever since these fields have become dominated by the paradigms of neo-positivism and methodological individualism (Cramer 2002; Baczko, Dorronsoro, and Quesnay 2018, pp. 2-18). To be sure, there has been substantial critique against simplistic accounts that reduces human motivation to take up arms to mere economic profiteering (e.g., Cramer 2002; Keen 2008; Malešević 2008). The spectre of economism haunts scholarship on and policy responses to armed conflict up until today, effectively depoliticising the actors, drivers, and the very nature of conflict itself. In fact, rebel groups today are often viewed primarily through the lens of the so-called "conflict-crime nexus," a perspective that has come to be particularly influential in formulating international policy responses (de Boer and Bosetti 2017). Pacification strategies born out of this understanding, such as the Dodd-Frank Act's provision on 'conflict minerals' in the eastern DRC, thus primarily aim at undercutting rebel revenues in order to make conflict less desirable and less feasible. In the case of Myanmar, army generals have not followed Western-led scholarship and policy. Their counterinsurgency strategies, however, are also tied to an economistic understanding of conflict and pacification. Here the state does not try to undercut smuggling revenues of rebel groups only. It also tries to consolidate its presence in restive border areas through co-opting non-state elites by way of economic incentives, and restive populations by way of economic development (Brenner 2019, pp. 110-111). What transpired clearly, though, from both scenarios is that scholars and policy makers need to move beyond an economistic understanding of conflict in order to address the political drivers of conflict, violence and insecurity.

\section{Notes}

1 The term pacification is chosen deliberately in order to highlight the fuzzy border between counterinsurgency, conflict resolution and peacebuilding practices. Some scholars see this nexus between peacebuilding and counterinsurgency as a pragmatic turn in peacebuilding, which partly stems from the failure of liberal peacebuilding and partly from the increased entanglements between counterinsurgency and peacebuilders in places such as Afghanistan and Iraq, where UN peacebuilding interventions cannot be viewed separately from US counterinsurgency wars (Moe and Stepputat 2018). Critical scholars highlight that analytically liberal peacebuilding has always been 'a form of riot control directed against the unruly parts of the world' to uphold liberal world order (Pugh 2004, p. 41). In 
many parts of the world, the technologies of peacebuilding and counterinsurgency are in fact not all too different (Turner 2015).

2 Myanmar's military rulers changed the name of the country from Burma to Myanmar in 1989. Using one or the other name has sometimes been contentious since. In recent years a scholarly consensus emerged to use Burma when discussing events prior to 1989 and Myanmar for events after 1989. This convention is followed here.

\section{References}

Andreas, P., 2011. Blue Helmets and Black Markets: The Business of Survival in the Siege of Sarajevo. Ithaca, NY: Cornell University Press.

Aronson, D., 2011. How Congress Devastated Congo. The New York Times. August 11.

Autesserre, S., 2006. Local violence, national peace? Postwar "settlement" in the Eastern DR Congo (2003-2006). African Studies Review, 49(3), 1-29.

Baczko, A., Dorronsoro, G., and Quesnay, A. 2018. Civil War in Syria: Mobilization and Competing Social Orders. Cambridge: Cambridge University Press.

Bafilemba, F., Mueller, T., and Lezhnev, S., 2014. The Impact of Dodd-frank and Conflict Minerals Reforms On Eastern Congo's Conflict. Washington, DC: Enough Project.

Berdal, M. and Keen, D., 1997. Violence and economic agendas in civil wars: Some policy implications. Millennium, 26(3), 795-818.

Brenner, D., 2019. Rebel Politics: A Political Sociology of Armed Struggle in Myanmar's Borderlands. Ithaca, NY: Cornell University Press.

de Boer, J., and Bosetti, L., 2017. The Crime-Conflict Nexus. United Nations University Centre for Policy Research. Crime-Conflict Nexus Series: No. 1. Available from: https://collections.unu.edu/eserv/ UNU:6429/Crime_conflict_nexus1.pdf [Accessed 2 March 2021].

Buchanan, J., 2016. Militias in Myanmar. The Asia Foundation. Available from: https:// asiafoundation.org/wp-content/uploads/2016/07/Militias-in-Myanmar.pdf [Accessed 2 March 2021].

Buhaug, H. and Gates, S., 2002. The geography of civil war. Journal of Peace Research, 39(4), 417-433.

Collier, P. and Hoeffler, A., 1998. On economic causes of civil war. Oxford Economic Papers, 50(4), 563-573.

Cuvelier, J., Van Bockstael, S., Vlassenroot, K., and Iguma, C., 2014. Analyzing the Impact of the Dodd-Frank Act on Congolese livelihoods. Social Science Research Council. doi: https://s3.amazonaws.com/ssrc-cdn1/ crmuploads/new_publication_3/analyzing-the-impact-of-the-dodd-frank-act-on-congolese-livelihoods.pdf

Cuvelier, J., Vlassenroot, K., and Olin, N., 2014. Resources, conflict and governance: A critical review. The Extractive Industries and Society, 1(2), 340-350.

Cramer, C., 2002. Homo economicus goes to war: Methodological individualism, rational choice and the political economy of war. World Development, 30(11), 1845-1864.

Duffield, M., 1999. Globalization and war economies: Promoting order or the return of history. Fletcher F. World Affairs, 23, 21.

Francis, J.N. and Mauser, G.A., 2011. Collateral damage: The 'War on Drugs', and the Latin America and Caribbean region: Policy recommendations for the Obama administration. Policy Studies, 32(2), 159-177.

Goodhand, J., 2004. From war economy to peace economy? Reconstruction and state building in Afghanistan. Journal of International Affairs, 58(1), 155-174.

Hedström, J. and Olivius, E., 2020. Insecurity, dispossession, depletion: Women's experiences of post-war development in Myanmar. The European Journal of Development Research, 32(7), 379-403.

Herbert, M., 2014. Partisans, profiteers, and criminals: Syria's illicit economy. Fletcher F. World Affairs, $38,69$.

Huntington, S.P., 1993. If not civilizations, what? Paradigms of the post-cold war world. Foreign Affairs, 72 (5), 186-194.

Jones, L., 2014. Explaining Myanmar's regime transition: The periphery is central. Democratization, 21(5), 780-802.

Kaldor, M., 2012. Kaldor, Mary, New and Old Wars: Organised Violence in a Global Era. 3rd ed. Cambridge: Polity.

Kaplan, R.D., 1994. The coming anarchy. Atlantic Monthly, 273(2), 44-76.

Keen, D., 2008. Complex Emergencies. Cambridge: Polity. 
de Koning, R., 2010. Conflict minerals in the Democratic Republic of the Congo. Stockholm International Peace Research Institute Policy Paper, SIPRI Policy Paper No. 27, Stockholm International Peace Research Institute.

Korf, B. and Raeymaekers, T., 2013. Introduction: Border, Frontier and the Geography of Rule at the Margins of the State. In: B. Korf and T. Raeymaekers, eds. Violence on the Margins: States, conflict, and borderlands. New York: Palgrave Macmillan, 3-27.

Lapaš, D., 2010. Sanctioning non-state entities. Revue internationale de droit pénal, 81(1), 99-124.

Laudati, A., 2013. Beyond minerals: broadening 'economies of violence' in eastern Democratic Republic of Congo. Review of African Political Economy, 40(135), 32-50.

Lavezzi, A.M., 2014. Organised crime and the economy: A framework for policy prescriptions. Global Crime, 15(1-2), 164-190.

Le Billon, P., 2012. Wars of Plunder: Conflicts, Profits and the Politics of Resources. New York: Columbia University Press.

Le Billon, P. and Nicholls, E., 2007. Ending 'resource wars': Revenue sharing, economic sanction or military intervention? International Peacekeeping, 14(5), 613-632.

Malešević, S., 2008. The sociology of new wars? Assessing the causes and objectives of contemporary violent conflicts. International Political Sociology, 2(2), 97-112.

Mamdani, M., 2018. Citizen and Subject: Contemporary Africa and the Legacy of Late Colonialism. Princeton, NJ: Princeton University Press.

Mappen, M., 2013. Prohibition Gangsters: The Rise and Fall of a Bad Generation. New Brunswick, NJ: Rutgers University Press.

McCoy, A.W., 1972. The Politics of Heroin in Southeast Asia. New York: Harper \& Row.

Meehan, P., 2011. Drugs, insurgency and state-building in Burma: Why the drugs trade is central to Burma's changing political order. Journal of Southeast Asian Studies, 42(3), 376-404.

Moe, L.W. and Stepputat, F., 2018. Introduction: Peacebuilding in an era of pragmatism. International Affairs, 94(2), 293-299.

Naylor, R.T., 1993. The insurgent economy: Black market operations of guerrilla organizations. Crime, Law and Social Change, 20(1), 13-51.

Parker, D.P., Foltz, J.D., and Elsea, D., 2016. Unintended consequences of sanctions for human rights: Conflict minerals and infant mortality. The Journal of Law and Economics, 59(4), 731-774.

Parker, D.P. and Vadheim, B., 2017. Resource cursed or policy cursed? US regulation of conflict minerals and violence in the Congo. Journal of the Association of Environmental and Resource Economists, 4(1), 1-49.

Prunier, G., 2008. Africa's world war: Congo, the Rwandan genocide, and the making of a continental catastrophe. Oxford: Oxford University Press.

Pugh, M., 2004. Peacekeeping and critical theory. International Peacekeeping, 11(1), 39-58.

Pugh, M.C., Cooper, N., Pugh, M., and Goodhand, J., 2004. War economies in a regional context: challenges of transformation. London: Lynne Rienner Publishers.

Rigterink, A.S., 2020. Diamonds, Rebel's and Farmer's Best Friend: Impact of Variation in the Price of a Lootable, Labor-intensive Natural Resource on the Intensity of Violent Conflict. Journal of Conflict Resolution, 64(1), 90-126.

Ross, M.L., 2004. What do we know about natural resources and civil war? Journal of peace research, 41(3), 337-356.

Saw Ralph and Naw Sheera, 2020. Fifty Years in the Karen Revolution in Burma: The Soldier and the Teacher. Ithaca, NY: Cornell University Press.

Seay, L., 2012. What's wrong with Dodd-Frank 1502? Conflict minerals, civilian livelihoods, and the unintended consequences of western advocacy, Working Paper No. 284, Center for Global Development.

Smith, M., 1999. Burma: Insurgency and the Politics of Ethnic Conflict. London: Zed Books.

Stoop, N., Verpoorten, M., and Windt, P. van der, 2018. More legislation, more violence? The impact of Dodd-Frank in the DRC. PLOS ONE, 13(8).

Turner, M., 2015. Peacebuilding as counterinsurgency in the occupied Palestinian territory. Review of international studies, 41(1), 73.

Turner, M. and Pugh, M., 2006. Towards a new agenda for transforming war economies. Conflict, Security \& Development, 6(3), 471-479.

Van Acker, F., 2005. Where did all the land go? Enclosure \& social struggle in Kivu (DR Congo). Review of African Political Economy, 32(103), 79-98. 
Vergara, J.C.G., 2014. Modernizing drug law enforcement in Latin America. Transnational Institute Series on Legislative Reform of Drug Policies, 29.

Verweijen, J., 2013. Military Business and the Business of the Military in the Kivus. Review of African Political Economy, 40(135), 67-82.

Vlassenroot, K., 2002. Citizenship, identity formation \& conflict in South Kivu: the case of the Banyamulenge. Review of African Political Economy, 29(93-94), 499-516.

Weigand, F., 2020. Conflict and Transnational Crime: Borders, Bullets \& Business in Southeast Asia. Cheltenham: Edward Elgar Publishing.

Wennmann, A., 2009. Getting Armed Groups to the Table: peace processes, the political economy of conflict and the mediated state. Third World Quarterly, 30(6), 1123-1138.

Wimmer, A., 2012. Waves of War: Nationalism, State Formation, and Ethnic Exclusion in the Modern World. Cambridge: Cambridge University Press.

Woods, K., 2011. Ceasefire capitalism: military-private partnerships, resource concessions and military-state building in the Burma-China borderlands. Journal of Peasant Studies, 38(4), 747-770. 